\section{Regioselective Biomimetic Oxidation of Etodolac with Iodosylbenzene Catalyzed by Halogenated and Perhalogenated Metalloporphyrins in Dichloromethane}

\author{
Shive M. S. Chauhan, ${ }^{*}$ Srinivas A. Kandadai and \\ Bishwabhusan SAHоO
}

Department of Chemistry, University of Delhi, Delhi-110 007, India. Received May 14, 2001; accepted July 30, 2001

The biomimetic oxidation of etodolac, an anti-inflammatory drug (1) with iodosylbenzene catalyzed by $5,10,15,20$-tetraarylporphyrinatoiron(III) chlorides TAPFe(III)Cl $(7 \mathrm{a}-\mathrm{e})$ in dichloromethane gives 4-hydroxyetodolac (6) and 4-oxoetodolac (5) regioselectively in moderate yields.

Key words etodolac; halogenated and perhalogenated metalloporphyrin; iodosylbenzene; 4-hydroxyetodolac; 4-oxoetodolac

Etodolac, 1,8-diethyl-1,3,4,9-tetrahydropyrano[3,4-b]-indole-1-acetic acid (1) is a clinically effective antiinflammatory agent, possesses an exceptional safety profile with respect to the gastrointenstinal tract and renal function. ${ }^{1,2)}$ The major primary oxidative metabolites of $\mathbf{1}$ in man are 6-hydroxyetodolac (2), 7-hydroxyetodolac (3), and 8-(1'-hydroxy)etodolac (4), whereas the major metabolite in rat is 4oxoetodolac (5). The biomimetic oxidation of selected drugs with monooxygen donors catalyzed by $5,10,15,20$-tetraarylporphyrinatoiron(III) chlorides (TAPFe(III)Cl) has been studied to understand the drug metabolism as well as to isolate the drug metabolites and reactive intermediates in sufficient amount without the use of experimental animals. ${ }^{3-6)}$ The catalytic activity of metalloporphyrins can be increased either by introduction of bulkier substituents at ortho position of the phenyl rings or by substitution of hydrogens by halogens of main porphyrin ring of metalloporphyrins (TAPFe(III)Cl). Herein, we report the biomimetic oxidation of etodolac with iodosylbenzene catalyzed by halogenated and perhalogenated iron(III) porphyrins TAPFe(III)Cl $(\mathbf{7 a}-\mathbf{e})^{7)}$ in organic solvents to mimic the reactions of natural cytochrome P450 enzyme.

Iodosylbenzene ( $1 \mathrm{mmol}, 220 \mathrm{mg}$ ) was added to a mixture of $1(1 \mathrm{mmol}, 287 \mathrm{mg})$ and $\mathrm{Cl}_{8} \mathrm{TPPFe}(\mathrm{III}) \mathrm{Cl}(\mathbf{7 b})(0.01 \mathrm{mmol})$ in dichloromethane $(10 \mathrm{ml})$. The reaction mixture was stirred for $2 \mathrm{~h}$ at room temperature. The solvent was removed under reduced pressure and the residue was chromatographed on silica gel. The elution of column with petrol: chloroform $(60: 40)$ gave 4-oxoetodolac ${ }^{8 a)}$ (1,8-diethyl-4-oxo-1,3,4,9tetrahydropyrano[3,4-b]-indole-1-acetic acid) (5), colourless solid, yield: $60.2 \mathrm{mg}, 20.0 \%, \mathrm{mp} 200-203^{\circ} \mathrm{C}$ (lit. ${ }^{3)} \mathrm{mp}$ $200-202{ }^{\circ} \mathrm{C}$ ). The appearance of a new band at $1732 \mathrm{~cm}^{-1}$ in the IR spectra of product (5) indicates the presence of new carbonyl group along with $-\mathrm{COOH}$ group. The disappearance of 3-H and 4- $\mathrm{H}$ coupling and appearance of a broad singlet for $3-\mathrm{H}$ at $\delta 4.28 \mathrm{ppm}$ in ${ }^{1} \mathrm{H}-\mathrm{NMR}$ spectrum confirms formation of $\mathbf{5}$. Again the structure of $\mathbf{5}$ is confirmed by the loss of 29 mass unit $\left(272, \mathrm{M}^{+}-\mathrm{C}_{2} \mathrm{H}_{5}\right)$ and again loss of 60 mass unit $\left(\mathrm{M}^{+}-\mathrm{CH}_{2} \mathrm{COOH}\right)$ from the parent ion peak.

The further elution of column with petrol:chloroform
(30:70) gave 4-hydroxyetodolac, ${ }^{8 b)}$ (1,8-diethyl-4-hydroxy1,3,4,9-tetrahydropyrano[3,4-b]-indole-1-acetic acid (6), colourless solid, yield: $72 \mathrm{mg}, 25.0 \%$; mp: $178-180^{\circ} \mathrm{C}$. The appearance of IR band at $3285 \mathrm{~cm}^{-1}$ in the IR spectra of the product (6) indicates the presence of $-\mathrm{OH}$ group. The disappearance of 4-H peak and appearance of 4-OH (brs) peak at $\delta 4.69 \mathrm{ppm}$ as well as the change in multipliticity of $3-\mathrm{CH}_{2}$ proton at $\delta 4.09 \mathrm{ppm}$ from triplet to doublet in the ${ }^{1} \mathrm{H}-\mathrm{NMR}$ spectra confirms the formation of $\mathbf{6}$. Further, the loss of 18 mass unit $\left(285, \mathrm{M}^{+}-\mathrm{H}_{2} \mathrm{O}\right)$ from the parent ion peak of 6 confirms the formation of $\mathbf{6}$.

The reaction of $\mathbf{1}$ with iodosylbenzene catalyzed by TPPFe(III)Cl (7a) in dichloromethane in after $2 \mathrm{~h}$ gives regioselctively $\mathbf{6}$ in $11.3 \%$ and 5 in $5.0 \%$ yield (Chart 1 ). The reaction of 1 with iodosylbenzene catalyzed by $F_{20}$ TPP$\mathrm{Fe}(\mathrm{III}) \mathrm{Cl}(\mathbf{7 c})$ in dichloromethane after $2 \mathrm{~h}$ gives $\mathbf{6}$ in $31.3 \%$ and 5 in $22.2 \%$ yield. Similarly, the oxidation of 1 with iodosylbenzene and perhalogenated metalloporphyrins like $\mathrm{Cl}_{8} \mathrm{Cl}_{8} \mathrm{TPPFe}(\mathrm{III}) \mathrm{Cl}$ (7d) and $\mathrm{Cl}_{8} \mathrm{Br}_{8} \mathrm{TPPFe}(\mathrm{III}) \mathrm{Cl}$ (7e) give $41.4 \%$ of $\mathbf{6}$ and $23.6 \%$ of $\mathbf{5}$ and $40.1 \%$ of $\mathbf{6}$ and $23.2 \%$ of $\mathbf{5}$, respectively. The reaction of $\mathbf{6}$ with iodosylbenzene catalyzed by $\mathrm{Cl}_{8} \mathrm{TPPFe}(\mathrm{III}) \mathrm{Cl}(\mathbf{7 b})$ gives 5 in $42.0 \%$ yield. Further the presence of strongly coordinating axial ligands like $N$ -

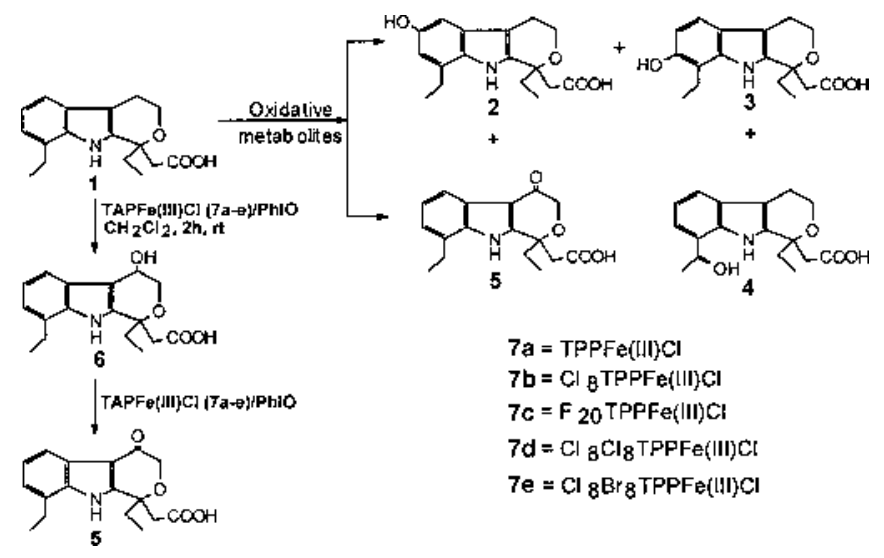

Chart 1

Table 1. Biomimetic Oxidation of Etodolac (1) with Iodosylbenzene Catalyzed 5,10,15,20-Tetraarylporphyrinatoiron(III) Chloride $(\mathbf{7 a - e})$ in Dichloromethane after $2 \mathrm{~h}$

\begin{tabular}{|c|c|c|c|}
\hline \multirow{2}{*}{ Entry } & \multirow{2}{*}{ System $^{a)}$} & \multicolumn{2}{|c|}{ Products $(\% \text { Yield })^{b)}$} \\
\hline & & 6 & $\mathbf{5}^{d)}$ \\
\hline 1 & 1/PhIO/TPPFe(III)Cl & 11.3 & 5.0 \\
\hline 2 & 1/PhIO/TPPFe(III)Cl/NMeIm & 17.0 & 9.4 \\
\hline 3 & 1/PhIO/Cl ${ }_{8} \mathrm{TPPFe}(\mathrm{III}) \mathrm{Cl}$ & $28.3(25.0)^{c)}$ & $20.8(20.0)^{c}$ \\
\hline 4 & 1/PhIO/Cl ${ }_{8} \mathrm{TPPFe}(\mathrm{III}) \mathrm{Cl} / \mathrm{NMeIm}$ & 39.2 & 28.3 \\
\hline 5 & 6/PhIO/Cl ${ }_{8}^{\circ} \mathrm{TPPFe}(\mathrm{III}) \mathrm{Cl}$ & - & 42.0 \\
\hline 6 & $\mathbf{1} / \mathrm{PhIO} / \mathrm{F}_{20} \mathrm{TPPFe}(\mathrm{III}) \mathrm{Cl}$ & 31.7 & 22.2 \\
\hline 7 & 1/PhIO/F $\mathrm{F}_{20} \mathrm{TPPF}(\mathrm{III}) \mathrm{Cl} / \mathrm{NMeIm}$ & 33.5 & 23.6 \\
\hline 8 & $\left.\mathbf{1} / \mathrm{PhIO} / \mathrm{Cl}_{8} \mathrm{Cl}_{8} \mathrm{TPPFe}(\mathrm{III}) \mathrm{Cl}^{e}\right)$ & 42.4 & 23.6 \\
\hline 9 & 1/PhIO/Cl ${ }_{8} \mathrm{Cl}_{8} \mathrm{TPPFe}(\mathrm{III}) \mathrm{Cl} / \mathrm{NMeIm}$ & 42.0 & 23.0 \\
\hline 10 & 1/PhIO/Cl ${ }_{8} \mathrm{Br}_{8} \mathrm{TPPFe}(\mathrm{III}) \mathrm{Cl}$ & 40.1 & 23.2 \\
\hline 11 & $\mathbf{1} / \mathrm{PhIO} / \mathrm{Cl}_{8} \mathrm{Br}_{8}^{\circ} \mathrm{TPPFe}(\mathrm{III}) \mathrm{Cl} / \mathrm{NMeIm}$ & 39.5 & 22.5 \\
\hline
\end{tabular}

a) Substrate : oxidant : catalyst : co-catalyst $=100: 100: 1: 10$. b) Yields were determined by HPLC analysis ( $\mu$-Bondapak) based on starting etodolac. $c$ ) Isolated yield. d) On over-oxidation, the yield of $\mathbf{6}$ decreases and $\mathbf{5}$ increases with increase of time, catalyst and oxidant. e) Two minor unidentified products were also observed. 
methylimidazole (NMeI) increased the yield of $\mathbf{6}$ from 11.3 to $43.0 \%$ and 5 from 5 to $24.0 \%$. These results were summarized in Table 1 . The addition of 1-methylimidazole as cocatalyst did not induce the larger differences in product yields, except with $\mathbf{7 b}$.

Although the aromatic ring hydroxylated and 8-ethyl hydroxylated metabolites are known but the pyrano ring hydroxylated metabolite, $\mathbf{6}$ is not detected in the metabolism of etodolac in human or rat. It is believed that $\mathbf{6}$ is a intermediate compound in the formation of another metabolite 4-ureidoetodolac. But with chemical model systems of cytochrome P450, unlike in vivo metabolism of etodolac, 6 is one of the major product in moderate yields.

The formation of $\mathbf{6}$ may be explained by abstraction of hydrogen radical from the allylic 4-position of etodolac by the high valent oxo-iron(IV) porphyrins and subsequent recombination of the etodolac radical with the hydroxy radical or hydroxy-iron(III) porphyrin present in the reaction medium. Further the formation of $\mathbf{5}$ can also be explained as over-oxidation of $\mathbf{6}$. Further the yield of 5 increases with increase of time, catalyst and oxidant. This type of hydrogen abstraction and recombination mechanism have been reported earlier with cytochrome P450 chemical model systems. ${ }^{9-13)}$ Although the decarboxylation of indole acetic acid ${ }^{14)}$ and ibuprofen ${ }^{15)}$ with hydrogen peroxide catalyzed by iron(III) porphyrins in aqueous and organic solvents has been reported, we have not observed the decarboxylation of etodolac in the above reaction conditions. Thus the above chemical model systems i.e., halogenated and perhalogenated iron(III) porphyrins $(\mathbf{7 a -}) / \mathrm{PhIO}$ may be used as efficient catalysts in the regioselective synthesis of two oxidative metabolites from etodolac in milder conditions.

Acknowledgement The authors are thankful to Council of Scientific and Industrial Research (CSIR), New Delhi, India for financial support.

\section{References and Notes}

1) Cayen M. N., Kraml M., Ferdinandi E. S., Gresejin E., Dvornik D., Drug Metab. Rev., 12, 339-362 (1981).

2) Humber L. G., Med. Res. Rev., 7, 1-28 (1987).

3) Higuchi T., Hirobe M., J. Mol. Catal. A: Chem., 113, 403-422 (1996).

4) Masumoto H., Takeuchi K., Ohta S., Hirobe M., Chem. Pharm. Bull., 37, 1788-1794 (1989).

5) Chauhan S. M. S., Chemical Models of Cytochrome P450 and Flavin Monooxygenase in Drug Metabolism, in 6th National Symposium on Bioorganic Chemistry, IISc, Bangalore, June 6, 1997.

6) Yang S. J., Nam W., Inorg. Chem., 37, 606-607 (1998).

7) Chauhan S. M. S., Ray P. C., Mohibb M., Azam E., Prakash S., Sharma T. K., J. Ind. Chem. Soc., 74, 199-201 (1997).

8) a) Data of 4-oxoetodolac (5): ${ }^{1} \mathrm{H}-\mathrm{NMR}\left(300 \mathrm{MHz}\right.$, DMSO- $\left.d_{6} / \mathrm{TMS}\right): \delta$ $0.83(\mathrm{t}, J=7.3 \mathrm{~Hz}, 3 \mathrm{H}), 1.34(\mathrm{t}, J=7.3 \mathrm{~Hz}, 3 \mathrm{H}), 2.01(\mathrm{~m}, 1 \mathrm{H}), 2.17(\mathrm{~m}$, $1 \mathrm{H}), 2.71-3.04(\mathrm{~m}, 4 \mathrm{H}), 3.06(\mathrm{~s}, 2 \mathrm{H}), 4.28(\mathrm{brs}, 2 \mathrm{H}), 7.01(\mathrm{~d}$, $J=9 \mathrm{~Hz}, 1 \mathrm{H}), 7.07(\mathrm{t}, J=9 \mathrm{~Hz}, 1 \mathrm{H}), 7.36(\mathrm{~d}, J=9 \mathrm{~Hz}, 1 \mathrm{H}), 8.59$ (br s, 1H), 11.23 (br s, $1 \mathrm{H})$; IR (KBr, cm ${ }^{-1}$ ): $3520,3345,1731,1632,1598$, 1499, 1463, 1307, 1261, 1079, 1018, 805, 675. EI-MS m/z: $301\left(\mathrm{M}^{+}\right)$, $272\left(\mathrm{M}^{+}-\mathrm{C}_{2} \mathrm{H}_{5}\right), 242\left(\mathrm{M}^{+}-\mathrm{CH}_{2} \mathrm{COOH}\right)$. b) Data of 4-hydroxyetodolac (6): ${ }^{1} \mathrm{H}-\mathrm{NMR}\left(300 \mathrm{MHz}\right.$, DMSO- $\left.d_{6} / \mathrm{TMS}\right) \delta \mathrm{ppm}$ : 0.89 (t, $J=7.3 \mathrm{~Hz}, 3 \mathrm{H}), 1.25(\mathrm{t}, J=7.3 \mathrm{~Hz}, 3 \mathrm{H}), 1.90-2.13(\mathrm{~m}, 2 \mathrm{H}), 2.64-$ $2.91(\mathrm{~m}, 2 \mathrm{H}), 3.27(\mathrm{~m}, 2 \mathrm{H}), 4.09(\mathrm{~d}, J=15 \mathrm{~Hz}, 2 \mathrm{H}), 4.30(\mathrm{~m}, 1 \mathrm{H}), 4$. $69(\mathrm{~s}, 1 \mathrm{H}), 5.09(\mathrm{~d}, J=15 \mathrm{~Hz}, 2 \mathrm{H}), 5.78(\mathrm{~s}, 1 \mathrm{H}), 6.94(\mathrm{~d}, J=9 \mathrm{~Hz}, 1 \mathrm{H})$, $7.06(\mathrm{t}, J=9 \mathrm{~Hz}, 1 \mathrm{H}), 7.37(\mathrm{~d}, J=9 \mathrm{~Hz}, 1 \mathrm{H}), 8.57$ (br s, $1 \mathrm{H}), 11.24$ (br s, 1H); IR ( $\left.\mathrm{KBr}, \mathrm{cm}^{-1}\right)$ : 3345, 3285, 1731, 1453, 1375, 1243, 1201, 1118, 1087, 1018, 926, 832, 750, 680; EI-MS $m / z$ : $303\left(\mathrm{M}^{+}\right) 285$ $\left(\mathrm{M}^{+}-\mathrm{H}_{2} \mathrm{O}\right)$.

9) Mansuy D., Battioni P., Battioni J. P., Eur J. Biochem., 184, 267-285 (1989).

10) Chauhan S. M. S., Gupta M., Gulati A., Nizar P. N. H., Ind. J. Chem., 35B, 1267-1270 (1996).

11) Chauhan S. M. S., J. Sci. Ind. Res., 56, 311-334 (1997).

12) Lindsey J. S., Wagner R. W., J. Org. Chem., 54, 828-836 (1989).

13) Chauhan S. M. S., Ray PC., Bioorg. Med. Chem. Lett., 1, 601-606 (1991).

14) Chauhan S. M. S., Mohapatra P. P., Kalra B., Kohli T. S., Satapathy S., J. Mol. Catal. A: Chem., 113, 239-247 (1996).

15) Chauhan S. M. S., Sahoo B. B., Bioorg. Med. Chem., 7, 2629-2634 (1999). 